\title{
Pengalaman Emosional Anak Usia Sekolah Melalui Menggambar Di Bangsal Anak Rs Dr. M. Djamil Padang
}

\author{
Dwi Novrianda ${ }^{a}$, Lenggogeni ${ }^{a}$ \\ ${ }^{a}$ Program Studi Ilmu Keperawatan FK UNAND \\ Email : dwinov_82@yahoo.co.id
}

\begin{abstract}
Hospitalisation is often stressful for children and sometimes are not able to verbally expressed. Drawing is a non-verbal communication techniques that can be used for exploring the emotional experience of children who are hospitalised with a non-threatening way. The purpose of this study was to determine the emotional experience of school-age children through drawing on the children's ward of Dr. M. Djamil Hospital in Padang. This study used qualitative methods with phenomenological approach. The study found three main themes: (1) a variety of reasons participants about the image created, (2) participants' response to a pleasant experience, and (3) participants' response to the sad and painful experience. It can be concluded that the expression of the emotional experience of school age children who are hospitalised through the drawing can deliver their thoughts and feelings and their response to emotional experience in the hospital something that is not fun.
\end{abstract}

Keywords: communication, drawing, emotional experience

\begin{abstract}
Abstrak : Hospitalisasi seringkali menimbulkan stres bagi anak dan kadangkala tidak mampu diungkapkan secara verbal. Menggambar merupakan teknik komunikasi non verbal yang dapat digunakan untuk mengeskplorasi pengalaman emosional anak yang dihospitalisasi dengan cara yang tidak mengancam. Tujuan dari penelitian ini adalah untuk mengetahui pengalaman emosional anak usia sekolah melalui menggambar di bangsal anak RS Dr. M. Djamil Padang. Penelitian ini menggunakan metode kualitatif dengan pendekatan fenomenologi. Hasil penelitian didapatkan tiga tema utama yaitu (1) berbagai alasan partisipan mengenai gambar yang dibuat, (2) respon partisipan terhadap pengalaman yang menyenangkan, dan (3) respon partisipan terhadap pengalaman yang menyedihkan dan menyakitkan. Dapat disimpulkan bahwa ungkapan pengalaman emosional anak usia sekolah yang dihospitalisasi melalui menggambar dapat menyalurkan pikiran dan perasaan mereka dan respon anak terhadap pengalaman emosinal di rumah sakit adalah sesuatu yang tidak menyenangkan.
\end{abstract}

Kata kunci: komunikasi, menggambar, pengalaman emosional

Penyakit dan hospitalisasi seringkali menjadi krisis pertama yang harus dihadapi anak. Anak-anak terutama selama tahuntahun awal, sangat rentan terhadap krisis penyakit dan hospitalisasi karena (1) stres akibat perubahan dari keadaan sehat biasa dan rutinitas lingkungan, dan (2) anak memiliki jumlah mekanisme koping yang terbatas untuk menyelesaikan stresor.
Stresor utama dari hospitalisasi antara lain adalah perpisahan, kehilangan kendali, cedera tubuh, dan nyeri. Reaksi anak terhadap krisis-krisis tersebut dipengaruhi oleh usia perkembangan mereka; pengalaman sebelumnya dengan penyakit, perpisahan; keterampilan koping yang mereka miliki dan dapatkan; keparahan diagnosis; 
dan sistem pendukung yang ada (Donna L. Wong et al, 2008).

Hospitalisasi telah lama dianggap sebagai pengalaman yang penuh dengan stres bagi anak-anak, tetapi derajat kecemasan yang dialami oleh anak tidak diketahui. Status fisiologis secara teratur diukur, tetapi tidak untuk status emosional (Clatworhyabc, Stephanie et al, 2003). Pernyataan ini juga diungkapkan oleh Pelander, Tiina et al (2003) bahwa tidak banyak yang diketahui tentang bagaimana anak-anak menyadari kualitas perawatan yang mereka terima selama di rumah sakit.

Wong, Dona et al (2008) mengatakan bahwa beberapa teknik komunikasi dapat digunakan untuk mengeksplorasi kekhawatiran anak dengan cara yang tidak mengancam. Akan tetapi, bagi sebagian besar anak-anak dan orang dewasa, membicarakan perasaan mereka adalah hal yang sulit dan komunikasi verbal justru dapat lebih menegangkan daripada mendukung. Dalam kondisi tersebut beberapa teknik nonverbal dapat digunakan untuk mendorong komunikasi. Salah satunya adalah melalui teknik menggambar.

Rollins, 1995 dikutip dalam Wong, Dona et al (2008) menyampaikan bahwa kebutuhan anak akan aktivitas seni atau aktivitas kreatif lainnya semakin kuat pada saat mereka dihospitalisasi. Wong, Dona et al (2008) mengutarakan bahwa anak-anak lebih mudah mengungkapkan pikiran dan perasaan mereka melalui seni, karena manusia pertama kali berpikir memakai imajinasi, kemudian belajar menerjemahkan imajinasi tersebut ke dalam kata-kata. Menggambar dan melukis merupakan media ekspresi yang sangat bagus. Perawat dapat menggunakan gambar anak sebagai salah satu alat untuk mendiskusikan pikiran, ketakutan, dan pemahaman terhadap konsep atau kejadian. Misalnya, gambar anak-anak sebelum pembedahan sering bermakna kekhawatiran yang tidak terungkapkan tentang mutilasi, perubahan tubuh, dan kehilangan pengendalian diri (Clarworthy,
Simon, dan Tiederman, 1999 dikutip dalam Wong, Dona et al, 2008).

Menggambar merupakan salah satu bentuk komunikasi yang paling berhargabaik nonverbal (dari melihat gambar) dan verbal (dari cerita anak tentang gambar tersebut). Gambar dari anak menceritakan banyak hal tentang mereka karena gambar tersebut adalah proyeksi dari dalam diri mereka sendiri (Wong, Dona et al, 2008).

Menggambar atau mewarnai bila sebagai suatu permainan yang "nondirective" memberikan kesempatan anak untuk bebas berekspresi dan sangat "therapeutic" (sebagai permainan penyembuh /"therapeutic play") (Whaley L.F, Wong D.L., 1991 dikutip dalam Suparto, Hardjono, 2006). Mengekpresi "feeling"nya dengan menggambar/mewarnai gambar, berarti memberikan pada anak suatu cara untuk berkomunikasi, tanpa menggunakan kata (Veltman M, W Browne K.D, 2000 dikutip dalam Suparto, Hardjono, 2006).

Seperti halnya menulis, menggambar pun dapat digunakan untuk mengekspresikan perasaan anak, seperti perasaan jengkel, marah yang biasanya dapat diungkapkan melalui gambar dan anak akan mengungkapkan perasaannya apabila perawat menanyakan maksud dari gambar yang ditulisnya. Perkembangan komunikasi pada anak usia sekolah dapat dimulai dengan kemampuan anak mencetak, menggambar, membuat huruf atau tulisan yang besar dan apa yang dilaksanakan oleh anak mencerminkan pikiran anak dan kemampuan anak membaca di sini sudah muncul, pada usia ke delapan anak sudah mampu membaca dan sudah mulai berfikir tentang kehidupan (Subianto, Teguh, 2009).

Gambar anak di rumah sakit dikembangkan sebagai alat untuk mengukur status emosional dari anak usia sekolah yang dihospitalisasi. Laporan menunjukkan validitas dan realibilitas dari gambar anak di rumah sakit sebagai pengukuran kecemasan untuk anak-anak yang dihospitalisasi 
(Clatworhyabc, Stephanie et al, 2003). Penelitian pada sebuah University Hospital di Finlandia terkumpul 35 gambar dari anak-anak berusia antara 4 dan 11 tahun selama mereka dirawat dan menunjukkan bahwa mereka mampu mengirimkan pandangan berharga ke dalam elemenelemen kualitas melalui media gambar (Pelander, Tiina et al, 2003).

Berdasarkan informasi dari perawat mengatakan bahwa anak-anak yang dirawat di ruang kronis RS Dr. M. Djamil Padang umumnya adalah klien dengan masa rawatan yang lama sehingga dapat menimbulkan kejenuhan dalam menjalani hospitalisasi. Dari hasil wawancara terhadap tiga orang anak juga mengatakan ingin segera pulang. Berdasarkan hal tersebut, peneliti tertarik untuk meneliti secara langsung pengalaman emosional anak usia sekolah melalui menggambar yang dirawat di bangsal anak RS Dr. M. Djamil Padang.

Tujuan dari penelitian adalah untuk mengetahui pengalaman emosional anak usia sekolah melalui menggambar yang dirawat di bangsal anak RS Dr. M. Djamil Padang.

\section{METODE}

Metode penelitian yang digunakan adalah metode kualitatif dengan pendekatan fenomenologi yang mengeksplorasi pengalaman emosional responden melalui gambar yang dibuat oleh anak dan dari cerita anak tentang gambar tersebut. Penelitian ini dilakukan di ruang rawat inap Anak (kronis dan akut) RS Dr. M. Djamil Padang selama 5 bulan pelaksanaan. Populasi dalam penelitian ini adalah pasien anak usia sekolah (6-12 tahun) yang dirawat di ruang kronis dan akut.

Variabel dalam penelitian ini adalah status emosional anak usia sekolah yang dinilai melalui gambar dan cerita anak. Data umum pasien yang dikumpulkan meliputi nama, umur, jenis kelamin, suku, agama, diagnosa medis, lama rawatan, frekuensi dirawat.
Prosedur penelitian ini dimulai dengan mengorientasikan partisipan dan keluarga terhadap tujuan penelitan dan dilanjutkan dengan meminta untuk menandatangani lembar persetujuan (informed consent) yang diajukan. Partisipan kemuadian diberikan alat-alat untuk menggambar (kertas, penghapus dan pensil warna). Selanjutnya partisipan diminta untuk menggambar secara spontan. Setelah partisipan menyelesaikan gambar, dilakukan evaluasi terhadap gambar yang dibuat oleh partisipan.

Analisa data dilakukan secara kualitatif menggunakan analysis content. Gambar yang dibuat oleh anak dikumpul dan dievaluasi, selanjutnya minta anak menceritakan gambar yang dibuat dan pengalaman di rumah sakit.

\section{HASIL DAN PEMBAHASAN}

Bagaimana pengalaman emosional anak usia sekolah (6-12 tahun) melalui menggambar selama dirawat di rumah sakit? Bagian ini akan menguraikan hasil penelitian dan pembahasan tentang pengalaman emosional anak usia sekolah yang dirawat di rumah sakit melalui menggambar. Sebanyak 12 anak usia sekolah yang dirawat di rumah sakit berpartisipasi dalam penelitian ini dengan menggunakan metode wawancara mendalam. Hasil penelitian ini dianalisis menggunakan langkah-langkah dari metode Colaizi (1978) untuk menghasilkan tematema esensial yang selanjutnya dideskrepsikan dalam bentuk naratif pada penyajian hasil penelitian ini. Hasil penelitian ini memunculkan 3 tema utama yang memberikan suatu gambaran atau fenomena pengalaman emosional anak usia sekolah yang dirawat di rumah sakit melalui menggambar.

Penyajian hasil penelitian dan interpretasinya dibagi menjadi 2 bagian. Bagian pertama menceritakan secara singkat gambaran karakteristik partisipan yang terlibat dalam penelitian ini meliputi usia, 
tempat tinggal, jenis kelamin, agama, alasan dirawat/diagnosa medis dan masa rawatan. Bagian kedua membahas analisis tematik tentang pengalaman emosional anak usia sekolah yang dirawat di rumah sakit melalui menggambar. Selanjutnya pada bab ini juga akan diuraikan keterbatasan penelitian yaitu kekurangan atau kesenjangan, dan hambatan-hambatan yang ditemui peneliti pada saat pelaksanaan penelitian

Partisipan dalam penelitian ini adalah anak usia sekolah yang dirawat di rumah sakit melalui menggambar. Sebanyak 12 orang partisipan berpartisipasi dalam penelitian ini. Jenis kelamin partisipan yaitu 8 orang $(66,67 \%)$ adalah perempuan dan 4 orang $(33,33 \%)$ adalah laki-laki. Sekitar 7 orang partisipan $(58,33 \%)$ berdomisili di Kota Padang dan 5 orang $(41,67 \%)$ yang lainnya berasal dari luar Kota Padang. Usia bervariasi dengan usia termuda 6 tahun 8 bulan dan usia tertua 12 tahun. Semua beragama Islam. Adapun alasan dirawat di rumah sakit bervariasi, sekitar 8 orang $(66,67 \%)$ dengan penyakit yang bersifat kronis seperti gagal jantung, penyakit ginjal, anemia, basalioma sedangkan 4 orang $(33,33 \%)$ dengan penyakit akut seperti diare, peritonitis, cephalgia e.c suspek SOL. Masa rawatan terpendek 3 hari dan terpanjang 10 hari.

Tema-tema yang dihasilkan dari penelitian ini dibahas secara terpisah untuk mengungkap makna atau arti dari berbagai pengalaman partisipan yang dirawat di rumah sakit melalui menggambar di RSUP M. Djamil Padang. Pada dasarnya tematema tersebut saling berhubungan satu sama lainnya untuk menjelaskan suatu esensi pengalaman emosional anak usia sekolah melalui menggambar.

Dari hasil penelitian pengalaman emosional anak usia sekolah yang dirawat di rumah sakit dihasilkan 3 tema utama diantaranya yaitu : (1) berbagai alasan partisipan mengenai gambar yang dibuat, (2) respon partisipan terhadap pengalaman yang menyenangkan, dan (3) respon partisipan terhadap pengalaman yang menyedihkan dan menyakitkan. Tema-tema tersebut terbentuk dari sub tema-sub tema yang akan diuraikan berdasarkan pernyataan-pernyataan partisipan sebagai berikut:

Berbagai alasan partisipan mengenai gambar yang dibuat :dengan pertanyaan kenapa anak membuat gambar tersebut? Hampir seluruh partisipan mengutarakan alasan masing-masing. 7 partisipan yang membuat gambar pemandangan menyatakan bahwa alasan menggambar pemandangan karena suka dengan pemandangan. Berikut pernyataan partisipan :

“indak . . . eh lai... pengalaman ... karena gunung ini adalah gunung Pasaman, (P1, red) orang Pasaman . . .”(P1).

"suka . . dan hanya bisa gambar pemandangan . . .tinggal dekat gunung. . ."(P2).

“... karena suka sama pemandangan ... “(P3).

“... suka sama bunga . . senang main sama bunga ...”(P5).

“...suka ... kalau pulang ke Kerinci suka lihat gunung ..."(P6).

"suka bunga,...suka kelapa...banyak bunga di rumah, ... sering minum air kelapa muda yang diberi kakak..."(P8).

“... soalnya di kampung ada orang yang berternak domba...trus tapi etek (P10,red) beternak sapi...tapi ara tertarik cuma sama domba...."(P10).

Gambar yang berbeda dibuat oleh 2 partisipan berikutnya, dengan alasan rindu sama rumah dan keinginan untuk pulang. Berikut pernyataan partisipan :

“... kangen ... ( $(P 7)$.

“... pengen pulang....”(P9).

1 orang partisipan menggambar mobil dengan ungkapan alasan berikut:

“. . . karena suka naik mobil ke pasar, pulang kampung dan ke laut ..."(P4).

1 orang partisipan lainnya hanya senyum sambil memainkan pensil di tangannya. 
Kemudian 1 orang yang membuat kaligrafi menyatakan bahwa :

“... suka saja menggambar ini ...”(P12).

Pada penelitian ini peneliti ingin mendapatkan gambaran alasan partisipan membuat gambar sesuai dengan apa yang dipikirkan atau dirasakan oleh partisipan. Penelitian mengidentifikasi bahwa semua partisipan menceritakan alasan tentang gambar yang dibuat. Berbagai alasan pembuatan gambar tersebut kemungkinan disebabkan oleh perasaan dan ingatan tentang kehidupan di luar rumah sakit dan kerinduan dengan rumah, lingkungan dan orang-orang terdekat partisipan.

Sebagaimana yang disampaikan oleh Johnson, 1990 bahwa gambar anak-anak adalah proyeksi (suatu bentuk komunikasi non-verbal) dari kepribadian mereka, bagaimana mereka melihat diri mereka sendiri, pengalaman mereka, dan pandangan mereka dari orang-orang penting dalam hidup mereka. Malchiodi, 1998 juga berpendapat bahwa gambar anak-anak yang dianggap mencerminkan dunia batin mereka, perasaan menggambarkan, informasi, status psikologis, dan gaya interpersonal (Tielsch, Anna H. \& Allen, Patricia J, 2005).

Johnson, 1990; Lukash, 2002, teknik penilaian proyektif sering digunakan untuk membantu anak-anak mengekspresikan emosi dalam pengaturan rumah sakit, dan penggunaan gambar adalah yang paling sederhana dari metode ini (Tielsch, Anna H. \& Allen, Patricia J, 2005). Dengan demikian, melalui metode menggambar ini mereka dengan jelas menyampaikan perasaan dan pikiran yang tersembunyi dimana anak-anak seringkali merasa sulit untuk berbicara tentang ketakutan mereka, frustrasi dan ketidakpastian kepada orang asing.

Respon partisipan terhadap pengalaman yang menyenangkan di rumah sakit untuk mengetahui pengalaman yang menyenangkan selama berada di rumah sakit, diajukan pertanyaan apa pengalaman yang menyenangkan selama di rumah sakit?
Hampir semua partisipan menjawab tidak ada dengan berbagai ekspresi sedih seperti menggeleng, menunduk, meringis dan mengigit bibir bawah. Berikut pernyataan 8 partisipan :

“.. tidak ada ...”(P1) (P4) (P9) (P12).

“... gak ada...”(P3) (P7) (P8).

“... gak ada, ... gak enak ...”(P6).

Selanjutnya 2 partisipan mengatakan

sebagai berikut :

“. . ada, main kartu sama adik ...”(P2).

"kadang main, ... kadang lalok, ... bercanda sama kakak. ."(P5).

Hanya 1 partisipan yang tidak menjawab tetapi menunjukkan ekspresi senang sambil memainkan jarinya dan 1 partisipan smengutarakan kegembiraannya ketika berada di rumah sakit, berikut pernyataan partisipan tersebut :

“. . . waktu Hari Anak Nasional, (P10, red) ikut acara itu... (P10, red) gak pake infus jadi Dokter membolehkan (P10, red) ikut... kemudian ibu perawat bercerita dan bertanya dan (P10, red) tau jawabannya, jadi (P10, red) jawab dan (P10, red) dapat hadiah, ... gelas dan celengan ...”(P10).

Dari hasil tersebut diketahui bahwa rumah sakit masih menjadi suatu tempat yang tidak menyenangkan dan memberikan pengalaman yang tidak menyenangkan bagi hampir sebagian anak. Hanya 1 partisipan yang menyampaikan adanya pengalaman menyenangkan saat berada di rumah sakit yaitu pada acara Hari Anak Nasional yang diselenggarakan oleh staf rumah sakit bagi anak-anak yang dirawat di rumah sakit tersebut. Hal ini menunjukkan bahwa rumah sakit bisa menjadi tempat yang menyenangkan bagi anak-anak yang dirawat dengan melaksanakan berbagai kegiatan permainan yang melibatkan anak.

Ellis, 2000 mengatakan bahwa bermain membantu memecah hambatan dengan anak-anak yang lebih kecil dan memungkinkan mereka untuk mengekspresikan perasaan mereka dan Haiait et al, 2003 juga mengutarakan bermain untuk mengurangi ketegangan, 
kemarahan, frustrasi, konflik dan kecemasan, yang terutama karena hilangnya perasaan kontrol dan harga diri (Glasper, A \& Richardson, J, 2006). Teknik yang digunakan untuk mengaktifkan anak-anak memproyeksikan apa yang mereka inginkan bisa menggunakan lukis, wayang, drama dan bercerita (Glasper, A \& Richardson, J, 2006). Sehingga dibutuhkan komunikasi secara efektif dengan anak, dengan mempertimbangkan perkembangan kognitif mereka, dan bermain harus menjadi bagian penting sebagai media perawat untuk menyelaraskan hubungan antara perawat dan anak.

Respon partisipan terhadap pengalaman yang menyedihkan dan menyakitkan di rumah sakit

Melalui pertanyaan coba ceritakan pengalaman yang menyedihkan maupun menyakitkan selama berada di rumah sakit. Semua partisipan menyampaikan jawabannya, berikut pernyataan partisipan :

“... yang menyedihkan... melihat umak menangis... melihat uda Rudi menangis...kalau yang menyakitkan... sakit kepala $(P 1$, red)... trus kalau disuntik, ... diinfus..."(P1).

“...disuntik.... yang menyakitkan... kaki gak bisa diluruskan,... jari-jari terasa sakit..."(P2).

"kalau yang menyedihkan ... sewaktu masukin obat ke dalam anus.... mmm...kalau sakit... sakit perut ... itu aja..."(P3).

"menangis karena sakit... trus disuntik ...”(P4).

“... sewaktu melihat amak marah karena (P5, red) gak mau minum obat, . . . (P5, red) jadi sedih ... trus sakit kalau diinfus atau disuntik..."(P5).

"ada.... kalau ingat orang-orang di rumah, ... adik, nenek, kakak, . . . pengen pulang..."(P6).

“. . . disuntik tiap hari . . “(P8).

“... disuntik ...”(P9).

"pernah,.. waktu itu (P10, red) dah bilang ke Dokternya jangan pasang pumpnya di situ karena pernah bengkak, tapi Dokternya tetap pasang pump di situ... sakiiit .... (P10, red) teriak... akhirnya gak bisa..baru setelah itu dipasang di tempat lain dan bisa..."(P10).

"Waktu itu (P10, red) liat anak di ruangan sebelah... Aisyah namanya, dia juga pandai... dia salah operasi... kata dokternya setelah dirontgen hasilnya kanker buli-buli trus dioperasi... perdarahan... trus ga bisa buang air kecil... dibuat tempat buang air kecil di perutnya... dia juga orang miskin... kasian (P10, red) liatnya.."(P10).

“... sambalnya ga da yang enak....”(P12).

Dari jawaban responden tersebut, diketahui bahwa pengalaman yang menyakitkan anak selama di rumah sakit adalah tindakan invasif seperti disuntik, diinfus, dan obat lewat anus dan pengalaman yang menyedihkan adalah melihat orang-orang terdekat dan orang lain sedih. Disini terlihat bahwa anak mau mengungkapkan perasaan mereka tentang pengalaman yang menyakitkan dan menyedihkan. Hal ini terjadi karena sebelum diwawancarai, anak diajak berkomunikasi melalui teknik permainan yaitu menggambar. Sehingga mereka merasa lebih percaya diri untuk menyalurkan pikiran dan perasaan. Oleh karena itu dibutuhkan komunikasi yang baik setiap pelaksanaan tindakan tersebut sehingga anak merasa aman dan nyaman. Selain itu, 2 orang partisipan hanya diam saat ditanya mengenai pertanyaan ini. Hal ini bisa disebabkan karena anak merasa tidak nyaman dengan orang baru dan belum ada rasa percaya yang terjalin.

Menurut Glasper, A \& Richardson, J, 2006 anak-anak sering merasa lebih mudah untuk berkomunikasi melalui permainan dan seni. Sharman (1997) menunjukkan berbagai strategi bermain untuk membangun hubungan terapeutik dengan anak. Ini pada gilirannya akan membuat anak merasa nyaman untuk kemudian mengungkapkan pikiran dan perasaan yang sebenarnya menjadi 
kekhawatiran mereka atau membuat mereka merasa tegang atau stres. Anak-anak belajar melalui bermain, itu adalah bagian alami dari kehidupan. Menyisihkan waktu untuk bermain memberi anak kesempatan yang ideal untuk mencari tahu tentang pengalaman rumah sakit mereka. Dengan demikian ketakutan mereka mungkin disembuhkan dan kemampuan mereka untuk mengatasinya dapat ditingkatkan (Glasper, A \& Richardson, J, 2006).

Dalam studi ini peneliti banyak menemui hal-hal baru dan tidak terduga. Keterbatasan yang pertama dalam penelitian ini adalah peneliti mendapatkan beberapa partisipan yang kurang mampu mengutarakan pengalamannya. Hal tersebut disebabkan oleh karena belum terjalinnya hubungan saling percaya antara klien atau partisipan, sehingga klien atau partisipan merasa kurang leluasa untuk membagi cerita. Fenomena lain terjadi pada saat penelitian berlangsung, keluarga partisipan turut memberi jawaban sehingga anak pun menjadi setuju dengan pernyataan tersebut. Partisipan kurang menceritakan pengalamannya sendiri, hal ini dapat mengakibatkan hasil penelitian kurang optimal.

Pada awalnya peneliti merencanakan jumlah responden adalah 30 orang, akan tetapi diakibatkan oleh kesulitan dalam mencari partisipan yang sesuai dengan kriteria inklusi, maka jumlah responden yang terlibat sebanyak 12 orang. Hal tersebut menjadi keterbatasan lain yang dialami dalam penelitian ini.

\section{KESIMPULAN DAN SARAN}

Berdasarkan tinjauan teori, hasil penelitian dan pembahasan, peneliti dapat mengambil kesimpulan bahwa anak usia sekolah (6-12 tahun) yang dirawat di Bangsal Anak RSUP Dr. M. Djamil Padang mengungkapan pengalaman emosional selama dirawat di rumah sakit melalui menggambar sebagai teknik komunikasi non verbal yang dapat menyalurkan pikiran dan perasaan anak usia sekolah. Respon anak terhadap pengalaman selama di rumah sakit adalah sesuatu yang tidak menyenangkan karena penuh dengan tindakan yang menyakitkan dan menyedihkan.

Berdasarkan temuan hasil penelitian dan analisa serta pembahasannya, maka peneliti menyarankan agar pendidikan tinggi keperawatan dapat meningkatkan ilmu, kemampuan dan keterampilan calon perawat dalam pelaksanaan asuhan keperawatan kepada anak melalui penyusunan dan perencanaan kurikulum yang sistematis dengan memperhatikan kompetensi dan metode pembelajaran serta melaksanakan evaluasi terhadap pelaksanaan kurikulum pendidikan keperawatan apakah sudah memenuhi tuntutan peran, wewenang dan tanggung jawab profesi keperawatan. Selanjutnya, bagi institusi pelayanan keperawatan agar dapat menjadi wadah dan lahan pembelajaran aplikatif dalam pelaksanaan asuhan keperawatan kepada anak dengan memperhatikan perkembangan keilmuan keperawatan terutama keperawatan anak. Selanjutnya, penelitian ini perlu dilanjutkan untuk melihat respon atau pengalaman hospitalisasi melalui metode lain komunikasi pada anak.

\section{DAFTAR PUSTAKA}

Clatworthyabc, Stephanie, et al. (2003). Child Drawing: Hospital-An instrument Design to Measure the Emotional Status of Hospitalized School-Aged Children. Volume 18. Journal of Pediatrics.

Glasper, A \& Richardson, J. (2006). A Textbook of Children's and Young People's Nursing. Toronto: Elsevier.

Hidayati, Nia. (2010). Manfaat Menggambar untuk Perkembangan Anak. Diakses melalui www.niahidayati.net pada tanggal 11 April 2011. 
Pelander, Tiina, et al. (2003). Children in The Hospital: Elements of Quality in Drawings. Volume 18. Journal of Pediatrics.

Speziale and Carpenter. (2007). Qualitative Research in Nursing: Advancing the Humanistic Imperative. 4th edition. Lippincott Williams \& Wilkins.

Subianto, Teguh. (2009). Komunikasi pada Anak. Diakses melalui www.teguhsubianto.blogspot.com pada tanggal 11 April 2011.

Suparto, Hardjono. (2006). Mewarnai Gambar sebagai Metoda Penyuluhan untuk Anak: Studi Pendahuluan pada Program Pemulihan Anak Sakit di IRNA Anak RSUD Dr. Soetomo Surabaya. Diakses melalui www.pediatrik.com pada tanggal 11 April 2011.

Tielsch, Anna H. \& Allen, Patricia J. Juli/Agustus (2005). Pediatric Nursing. Listen To Them Draw: Screening Children in Primary Care Through the Use of Human Figure Drawings. 31, 4.

Wong, Dona L., et al. (2008). Buku Ajar Keperawatan Pediatrik Wong. Jakarta: EGC. 